\title{
Influential Variables in Learning Assessment to the Vocational Competency Enhancement, Character Education and Formation of Student Creativity
}

\author{
Eddy Sutadji \\ State University of Malang, Indonesia \\ eddy.sutadji.ft@um.ac.id
}

\author{
Agus Wedi \\ State University of Malang, Indonesia \\ agus.wedi.fip@um.ac.id
}

\begin{abstract}
The research objective is to obtain: (1) data on the impact of the successes and constraints in implementation of the evaluation model based training curriculum 2013; (2) the influential variables of vocational competence improvement; and (3) assessment of learning outcomes are effective and easy to use at SMK. The design of the study, the combination of research and development as well as a descriptive study. The study population is a stakeholder SMK Negeri Malang, while the sample is 13 Principal SMK, Supervisors, Head of the Department of Education Curriculum, expert evaluation of learning and education, as well as document the results of the analysis item in the collection SMK. Technique FGD, questionnaires, and documentation. The data analysis technique used is descriptive statistics. conclusions research: (1) there are still many obstacles in the concepts, principles, and procedures for the implementation of Curriculum 2013 at SMK Malang; and (2) the ability of vocational teachers in the development of items, judging from the results of the analysis of the level of difficulty, distinguishing, functioning distractors, and reliability, the average was below standard. Less good quality items and less viable as a measure of student competence.
\end{abstract}

Keywords: influential variables, assessment of learning, vocational competence, character education, student creativity

\section{INTRODUCTION}

Research results from Sutadji \& Wedi (2015) presented the following data: based on the subjects in vocational, 'Normative' lessons relatively easy (54\%); 'Adaptive' lessons relatively easy (79\%), and 'Productive' lessons relatively easy (40\%). Details of the details are presented below: (1) item difficulty based subjects in vocational mostly easy, detailed as follows: 'normative' lessons $54 \%$ easy, $46 \%$ medium, $0 \%$ difficult; 'adaptive' lessons $79 \%$ easy, $11 \%$ moderate, $10 \%$ is difficult; and 'productive' lessons $40 \%$ easy, $40 \%$ medium and $20 \%$ difficult; (2) the index different power items based subjects in vocational mostly easy, detailed as follows: 'normative' lessons $4 \%$ excellent, $49 \%$ good, $46 \%$ revised / removed, 'adaptive' lessons $23 \%$ excellent, $30 \%$ good , $46 \%$ of the revised / removed, and 'productive' lessons $8 \%$ excellent, $41 \%$ good, $51 \%$ revised / removed; (3) reliability item based vocational subjects in detail as follows: high category $47 \%$, was $32 \%$, is very high (16\%); and (4) functioning distractors items based subjects in vocational mostly not functioning properly, detailed as follows: 'normative' lessons $47 \%$ working, $53 \%$ had to work; 'adaptive' lessons 5\% working, 95\% have not been functioning; and 'productive' lessons $47 \%$ working, $53 \%$ have not been functioning.

Data research findings Sutadji \& Wedi (2016) the following: (1) the competences of vocational teachers in understanding the concept of assessment authentic in the learning process $67 \%$ know well, develop items $46 \%$ know very well, and the analysis of item $33 \%$ know well; (2) the need for teachers in understanding the assessment of authentic $63 \%$ is needed, step-by-step preparation of items $50 \%$ is needed, and the analysis of item $71 \%$ is needed; (3) components of a conceptual model of evaluation of vocational education refers to the curriculum in 2013 has eligibility an average of $80 \%$ can be used in schools; and (4) effectiveness evaluation of conceptual models of vocational education in the learning of the average $82 \%$ can be used effectively. Based on the above data, it is necessary to do research to find a solution how to develop, implement, and assess appropriate learning curriculum 2013.

Based on the condition of education in schooling levels filled with problems, particularly related to the quality of vocational education it is necessary to find solutions to answer. One alternative to overcome the gap between the real condition and the ideal: is the Developing Evaluation Model-Based Vocational Education Curriculum 2013. The research objective is to obtain: (1) data on the impact of success and obstacles in the implementation of evaluation model curriculum-based vocational education 2013; (2) the variables affect the improvement of vocational competence; and (3) assessment of learning outcomes are effective and easy to use on the CMS.

\section{Character Building}

Character education is an overall relational dynamics of interpersonal with various dimensions, both from within and from outside himself, so personally it's getting to live his freedom, so that they can be responsible for the growth of herself as a person and the development of other people in their lives (Koesoema, 2010) and Rohman (2013). According Santrock (2012), character education is a direct approach to moral education involving basic moral teaching for the learners to prevent them from engaging in immoral behavior and do things that are harmful to themselves or others. The behavior of lying and cheating is wrong, learners should be taught about it at all times of their education.

Lickona (2012) and Boggs, et al (2010) explain, the right character for the educational value of the character that consists of operative values, values in action. We proceed in our character as a value into a virtue, a disposition that can be relied upon to respond to situations in a way that moral good. Characters who feels thus has three interrelated parts: moral knowledge, moral feeling and moral behavior. Good 
character consists of knowing a good thing, wanting a good thing, and to do good things in the way of thinking, habits of the heart, and habits in action.

Samani (2012) explains, the identification number of the value of the formation of character is the result of empirical studies center of the curriculum have values derived from religion, Pancasila, culture, and national education goals are: (1) religious (2) honest ( 3) tolerance (4) discipline (5) hard work (6) a creative (7) independent; (8) demokratif; (9) curiosity; (10) the national spirit; (11) love of the homeland; (12) recognize excellence; (13) friends / communicative; (14) love peace; (15) likes to read; (16) care for the environment; (17) social care; and (18) responsibility.

Character education is expected to make changes in the attitudes, behaviors, values of life, and test scores of learners. The impact of character education is the increasing attitude of learners, increasing the behavior of learners, increasing learner performance, satisfaction of parents that their children have both behaviorally and academically, increased motivation of teachers for the purpose of realizing the behavior and academic can be met with ease, increasing productivity and class performance, increased support and partnership becomes larger, learners are not destructive to the existing norms, the students can achieve academic potential of their full and maximum, learners can successfully enter and compete in the workplace, and learners can contribute means for their community to uphold the tradition and values in society through participation in social and economic order that exists.

\section{Creative Thinking}

Creative thinking is the thinking that generates new methods, new concepts, new understandings, new discoveries and new artwork. It is the very root of human progress. Creativity comes from the Latin word Creatus, which means making an obedience or adherence to a practice, that is, to bring out the creativity inherent in a person to use real practice (Suharnan, 2011), while Bleetlestone (2012) confirmed that the process creative involves selecting the elements that are known from various fields and incorporate them into new formats, use the information in new situations, describing aspects of experience, patterns nalogi and fundamental principles unrelated.

This aspect allows the person being to solve the problem to bring different solutions and that was not clearly visible. Things that are unexpected happened, without intention or cause that can be observed, also referred to in the process of creative thinking.

Based on the description above, learners can think creatively from the interaction between the learner and his environment. Environment that can stimulate the emergence of creative ideas, give encouragement when creative ideas put forward by someone, and reward (reward) for ideas and creative behaviors, will nourish and enrich the birth of ideas orijinal and nonconformist. More specifically, in the process of learning both in the classroom and outside the classroom needs to be given a stimulus for learners to think creatively.
The school environment is also participating in the process of providing stimulus for learners to think creatively, so if all that is done then there is no doubt the students will be to be able to think creatively which is expected on kompensi achievement of learners.

\section{Vocational Competency}

Spencer and Spencer considers that the competence as prominent characteristics of an individual associated with effective performance and / or superior in a job or situation (Uno, 2011). Uno (2011) himself concluded that the competence or ability is referring to a person's performance in a job that can be seen from the thoughts, attitudes, and behavior.

Darmaningtyas understands competency as natural ability needed for someone to do something effective (Ilahi, 2012). Ilahi itself (2012) states in terms of education, competence is performance that looked at the ability shown (observable) and measurable.

Billett (2011) explains, Some view the development of Generally Applicable competencies as being the most worthwhile use of educational resources and provisions. The more recent versions of Generally Applicable Reviews These capacities are the core competencies that have been developed to guide learning of general employability capacities (eg problem solving, strategies, communication).

Reviews These core competencies have been proposed by Reviews their sponsors as being adaptable to the range of employment circumstances that individuals will encounter across Reviews their working lives. Occupational competence requires the capacities to berkomunikasi, get on with others, and have an understanding of and sensitivity towards cultural factors. Equally, the ability to berkomunikasi, be numerate and literate, and engage with others is all in some way shaped by the domains of activity in the which they are applied,

Some experts argue that the development of competencies in general serves as the use of educational resources are most valuable. Competence includes the ability to solve problems, strategy, and communication, a skill that is used to adapt to different types of work situations to be faced by every individual in working life. Job competence requires the capacity to communicate, get along with others, and an understanding of and sensitivity to cultural factors.

\section{METHODS}

The research design, using a combination of research and development (Reeves, et al, 2006) as well as a descriptive study. The study population is a stakeholder SMK Negeri in Malang, while the sample is 13 Principal SMK, Supervisors, Head of Curriculum Education Department of Malang, three expert evaluation of learning and education, as well as document the results of the analysis item in SMK. Technique data collection using Focus Group Discussion (FGD), questionnaires, and documentation. The data analysis technique used is descriptive statistics. 


\section{RESULT}

Description of Implementation Success Impact and Constraint of Evaluation Model

Development of a model evaluation of curriculum-based vocational education in 2013 as an effort to produce learners character and creative thinking to achieve vocational competence, starting first with the excavation of impact the success and obstacles in the implementation model of curriculumbased vocational education evaluation in 2013 as well as variables affect the improvement of vocational competence. Data mining is done through focus group discussions (FGD) on August 27, 2016 at the LP3 Hall, H7 Building, State University of Malang. Implementation of the FGD concluded several matters related to the impact of the successes and obstacles in the implementation of evaluation models based training curriculum 2013, as follows.

1. Policy Malang City Department of Education has set the entry into force of Curriculum 2013 (Kemdikbud, 2013).

2. The whole SMK in Malang has implemented Curriculum 2013.

3. Through the School Principals' Working Group forum (MKKS) SMK, Deliberation Subject Teacher (MGMPs) vocational school, and the teachers have obtained socialization curriculum implementation in 2013.

4. Vocational teachers have attended socialization implementation of Curriculum 2013.

Thus, concepts, principles and procedures for the implementation of Curriculum 2013 has been communicated to all stakeholders in vocational schools in the city of Malang. Constraints application of evaluation model of vocational education, among others:

1. There is data that reveals that the value of graduate students with curriculum implementation in 2013 is lower than that applying the SBC.

2. Lack of understanding the perception of K-13 to be one problem less optimal implementation of the $\mathrm{K}-13$ in the field.

3. Minimum Mastery Criterion (MMC/KKM) imposed determination can be an obstacle for teachers to be able to carry out an objective evaluation.

4. Still there are inconsistencies between the theorypractice assessments on subjects matter productive due to factors that are not standard.

5. Many other non-instructional factors that also contributed in student learning outcomes, such as the problem of students who generally come from problems at home.

6. The implementation of Curriculum 2013, to the potential problem of not macth with dapodik developed school system.

7. During the determination of Minimum Mastery Criterion (MMC/KKM) is not supported by appropriate prerequisites, they often copy and paste from existing ones.

8. There are still inconsistencies between the value of report cards and national exams.
9. Learning outside school (prakerin), the industry, there is no standardization, as well as aspects of the judgment.

10. Teachers are not adequately controlled and the use of verbs determination operations required in the assessment tool.

\section{Result of Items Analysis in 26 Lessons at SMK Level of Difficulty}

Multiple Choice form with ANATES

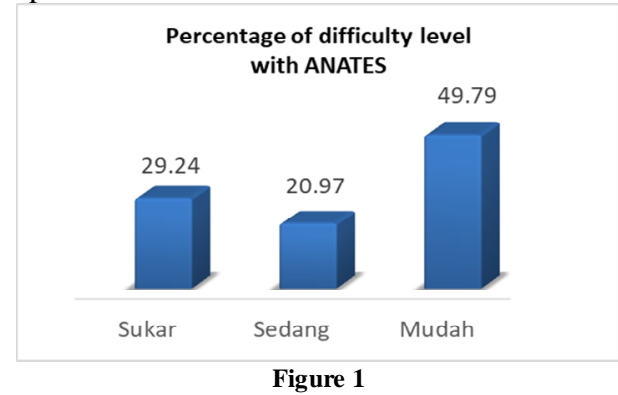

Hard Moderate Easy

Table 1

The Distributions of Frequency

\begin{tabular}{clcc}
\hline No & Category & Frequency & Percentage \\
\hline 1 & Hard & 212 & 29.24 \\
2 & Moderate & 152 & 20.97 \\
3 & Easy & 361 & 49.79 \\
\hline
\end{tabular}

Description (Essay) form with ANATES

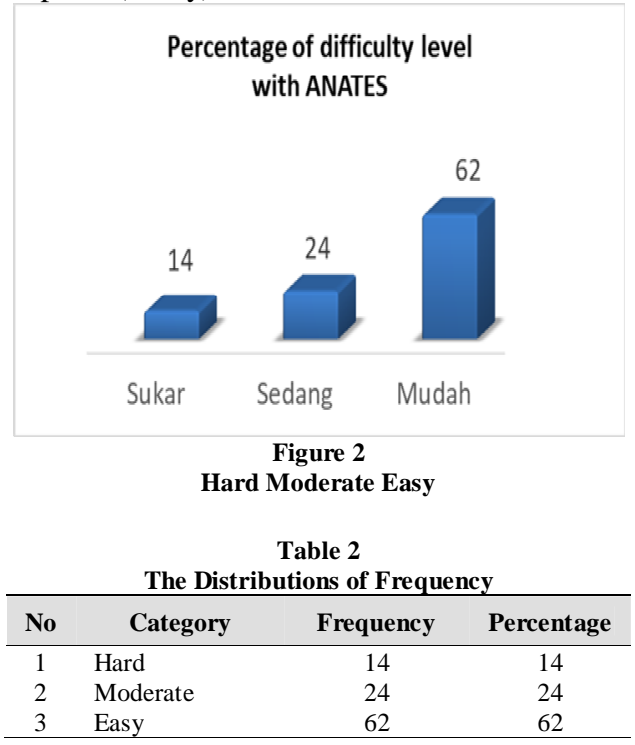

Multiple Choice form with ITEMAN

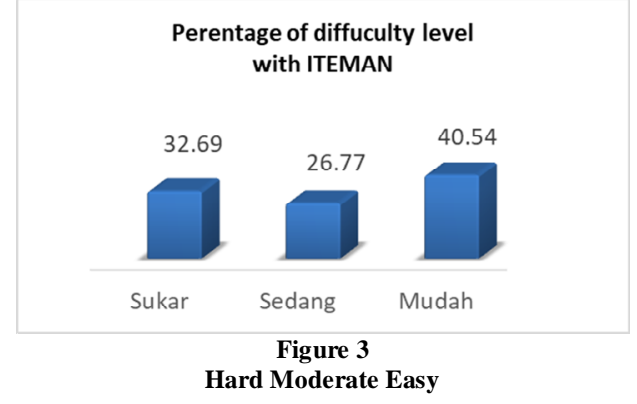


Table 3

The Distributions of Frequency

\begin{tabular}{clcc}
\hline No & Category & Frequency & Percentage \\
\hline 1 & Hard & 304 & 32.69 \\
2 & Moderate & 249 & 26.77 \\
3 & Easy & 377 & 40.54 \\
\hline
\end{tabular}

Results of Distinguishing Power Level Analysis Multiple Choice form with ANATES

Percentage of distinguishing power level
with ANATES

Description (Essay) form with ANATES

Percentage of distinguishing power leve with ANATES

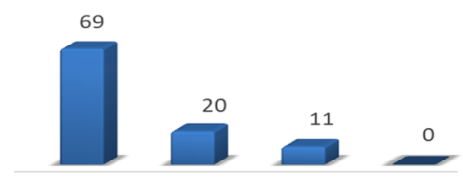

Revission - Moderate - Good -- Very good

Figure 5

Description (Essay) form with ANATES

Table 5

The Distributions of Frequency

\begin{tabular}{clcc}
\hline No & \multicolumn{1}{c}{ Category } & Frequency & Percentage \\
\hline 1 & Revision / remove & 69 & 69 \\
2 & Moderate & 20 & 20 \\
3 & Good & 11 & 11 \\
4 & Very good & 0 & 0 \\
\hline
\end{tabular}

Multiple Choice from with ITEMAN

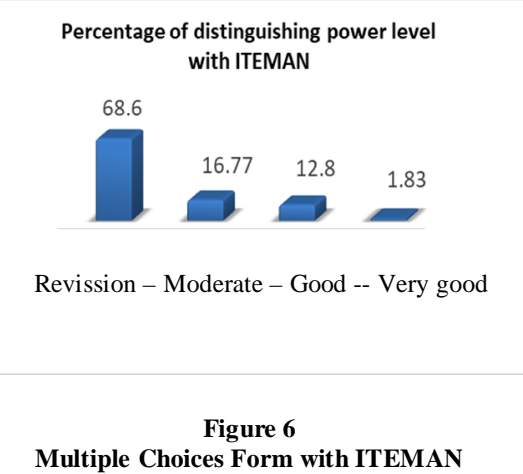

Table 6

The Distributions of Frequency

\begin{tabular}{clcc}
\hline No & \multicolumn{1}{c}{ Category } & Frequency & Percentage \\
\hline 1 & Revision / remove & 638 & 68.6 \\
2 & Moderate & 156 & 16.77 \\
3 & Good & 119 & 12.8 \\
4 & Very good & 17 & 1.83 \\
\hline
\end{tabular}

Results of the functioning of detractors (distractors) Analysis

Multiple Choice form with ANATES

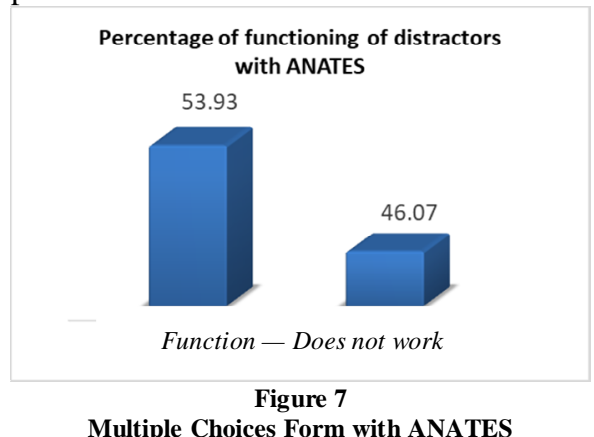

Table 7

The Distributions of Frequency

\begin{tabular}{clcc}
\hline No & Category & Frequency & Percentage \\
\hline 1 & Function & 391 & 53.93 \\
2 & Does not work & 334 & 46.07 \\
\hline
\end{tabular}

Multiple Choice form with ITEMAN

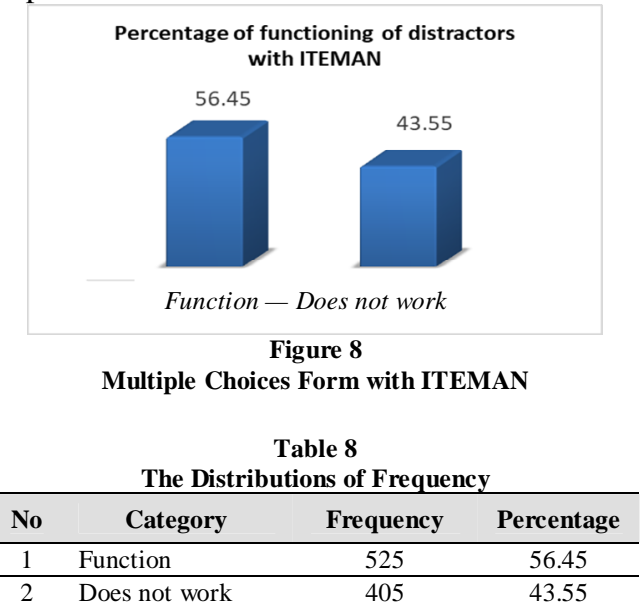

Results of Reliability Item Analysis

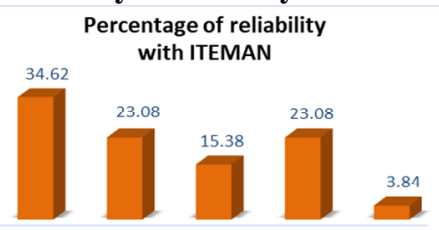

Very low-Low-Enough-High-Very high

Figure 9

Reliability Item Analysis 
Table 9

The Distributions of Frequency

\begin{tabular}{clcc}
\hline No & Category & Frequency & Percentage \\
\hline 1 & Very low & 9 & 34.62 \\
2 & Low & 6 & 23.08 \\
3 & Enough & 4 & 15.38 \\
4 & High & 6 & 23.08 \\
5 & Very high & 1 & 3.84 \\
\hline
\end{tabular}

From the description above: (1) there are still many obstacles in the concepts, principles, and procedures for the implementation of Curriculum 2013 at SMK Malang; and (2) the ability of vocational teachers in the development of items, judging from the results of the analysis of the level of difficulty, distinguishing, functioning distractors, and reliability, the average was below standard. Less good quality items and less viable as a measure of student competence. Implementation of the FGD, the result of in-depth interviews, and empirical studies in the field concluded several matters related to the variables affect the improvement of vocational competence, as follows:

1. Teachers practice in the field is in need of practical application program that is easy to apply ratings.

2. It takes a training workshop on assessment for teachers.

3. Description of competence need to be clarified and Break down so that the development of assessment can be done more easily.

4. Emphasis the need for a paradigm that is not merely Assessment of Learning, but rather the Assessment for Learning.

5. Alternative assessment is required to assess the achievement of student learning.

6. Whether we realize the necessity of the principal responsibilities towards learning as an important aspect.

7. Student assessment should be able to describe keaadaan / actual ability of students to learn.

8. Understand the teacher's position as the executor of policies that are currently in place.

9. It is recommended that special for vocational students, the assessment of the first and main priority is the students' attitude.

10. Disciplinary cadets (ketarunaan) as habituation for students deemed highly effective form of discipline and attitude.

11. It is recommended that Minimum Mastery Criterion (MMC/KKM) for CMS could be raised in order to be sold on the world of work.

From the above explanation, it can be identified that influence the variables in the application of evaluation model of vocational education are:

1. Implementation of the learning process in the classroom is not optimal.

2. The competence of teachers to understand the learning outcomes assessment, which is the use of authentic assessment is still not optimal.

3. Student competence in various domains in the field of vocational, does not depict actual ability.

4. Policies principals regarding the development ability of teachers to carry out the measurement, assessment, and evaluation of the authentic needs to be improved through media training.

5. Emphasis pemahanan paradigm of assessment for learning, not just assessment to learning on the teacher as a base assessment of learning outcomes.

6. Completeness of facilities and infrastructure implementation of authentic assessment in the form of authentic assessment guides, guide learning outcomes assessment, and capability development items as well as analysis of items that are simple, easy to implement, a major requirement of teachers in assessment exercise correctly.

\section{DISCUSSION}

Based on the above results, the findings supported Burhan \& Pujiati (2009) that: (1) the teacher did not understand and did not make authentic assessment in language learning in the classroom despite it being one of the assessments recommended in the SBC. Teachers need of upgrading and authentic assessment deployment training to be able to apply them in the classroom; (2) teacher empowerment strategies in authentic assessment can be reached through upgrading, training, and assistance in drafting and implementing practice of authentic assessment. Through the way it looks teacher began to understand and be able to make an evaluation tool model of authentic assessment that can be applied in their respective classes; (3) the teacher and colleagues hope guidebooks containing the concept of authentic assessment, actually to measure language competence, language is simple, easy followed, and there are examples of the assessments and measures. The teachers think more practically, how guidebooks in question can be easily implemented in the classroom to assess learning outcomes language competence; and (4) guidebook authentic assessment made be made to accommodate these expectations.

Therefore, Authentic Assessment Implementation Model-Based Classroom modification of Moya and O'Malley (in Singh, Samad, \& Husen, 2015), known as Portfolio Assessment Model, can be used as a form of authentic assessment. In the model, the associated assessment for learning contains three learning components, including planning, implementation, analysis and reporting. The planning component, including: (1) determine the purpose and focus, such as basic competencies, indicators of achievement of competencies, domains assessed; (2) plan the content of authentic assessment that includes: the election procedure of assessment, determine the content / topic, and set the frequency and timing of assessment; (3) designing a way of analyzing the data, ie to set: standard or criteria, define how to integrate the assessment results from different sources, for example from the performance, portfolio evaluation, and set the time of analysis; (4) to plan the steps to the assessment (integrated in learning, there are activities in providing feedback, assessment process, assessment of the product); and (5) determine the procedure for testing the accuracy of information, which define how to determine the validity and reliability of assessment information. 
Component implementation / execution, contains: (1) announce the purpose and focus of learning to students; (2) agree on the procedure of assessment used and the assessment criteria; (3) to discuss ways that need to be done to achieve maximum results; (4) conducting assessments in accordance with the planning and agreement (data collection); and (5) provide feedback, while the components of the analysis and reporting, including: analyzing the data collected; integrating the results of the analysis of various data obtained; applying the final assessment criteria; and report the results of the assessment.

Theoretically and empirically, penggembangan and implementation of authentic assessment tool in accordance with Selfi, Muhardjito, \& Sutadji (2016) and Cunningham (1998) that the classroom teacher is the users and implementers because the assessment is an integral part of learning to understand the teacher, in addition to the teachers to be skilled in assessment methods development, administration, scoring, and interpreting the data results of the assessment. To achieve effectiveness assessment, students are required to know some aspects that will be evaluated during the assessment process. This should also be done by the teacher to provide information on aspects that will be evaluated.

\section{CONCLUSION AND SUGGESTION}

The conclusion of this study are: (1) SMK has been implementing authentic assessment in the classroom, although not optimal, whereas the main obstacles is the need for assistance in the implementation of a class; (2) the variables affect the improvement of vocational competence to do with character education and formation of students' creativity, among others, the implementation of the learning process and the implementation of appropriate assessments, teacher competence in developing items, as well as the emphasis on assessment for learning, not just assessment to learning; and (3) there needs to be an effective learning assessment guide and easy to use CMS.

Advice can be given in this study are: (1) vocational students can take advantage of authentic assessment in the learning process the teachers to: getting a positive impact on the implementation of learning that teachers that learning and assessment is an integral part; and establish a vocational competence of vocational students are real, especially in terms of knowledge, skills, and attitudes (characters) in accordance with the expectations of the implementation of Curriculum 2013; (2) vocational teachers always develop authentic assessments to: media self-reflection on the development of assessment tools were developed; develop test and non-test of authentic assessment; analyzing items qualitatively and quantitatively; and describe map the ability of students through authentic assessment developed; (3) Deliberation Subject Teacher (MGMP) constantly upgrade and update the assessments authentic with: disseminate and develop quality items to members MGMP in schools and education offices; and disseminating analysis of items with the ANATES and
ITEMAN; and (4) rincipal SMK through Sustainable Teacher Professional Development (PKB) to: improving the ability of teachers to develop a good item; and improving the ability of the teacher to analyze items qualitatively and quantitatively.

\section{REFERENCES}

[1] Billett, S. 2011. Vocational Education Purposes Traditions and Prospects. Griffith: Spinger.

[2] Beetlestone, F. 1998. Creative Learning. Bandung: Nusa Media.

[3] Boggs, G., Cori, J., Peter, S., \& Amy, A. W. 2010. The Implied Character Curriculum in Vocational and Nonvocational English Classes: Designing Social Futures for Working Class Students and Their Teachers. Journal of Research in Character Education, $8(2)$.

[4] Burhan, N. \& Pujiati, S. 2009. Development of Authentic Assessment Model in Learning English. Education Horizon, 28(3).

[5] Cunningham, G. K. 1998. Assessment in the Classroom: Constructing and Interpreting Test. New York: Falmer Press.

[6] Lickona, T. 1991. Education for Character: How Our Schools can Teach Respect and Responsibility. Jakarta: PT Bumi Aksara.

[7] Kemendikbud. 2013. Curriculum 2013. Jakarta: Kemendikbud.

[8] Koesoema, D. 2010. Educating Children Character Education Strategy in the Global Age. Jakarta: Grasindo.

[9] Prayitno. 2007. Influence of Media Education and Creative Thinking Level Against Student Achievement In Competence Maintain / Service air conditioning systems in SMKN I Seyegan Sleman. Thesis. Malang: State University of Malang.

[10] Reeves, T. C., McKenney, S., \& Herrington, J. 2006. Publishing and Perishing: The Critical Importance of Educational Design Research. Sydney: Ascilite.

[11] Rohman, M. 2012. Curriculum Character (Reflection and Proposal Solution to the $C B C$ and $S B C$ ). Jakarta: Prestasi Pustaka.

[12] Samani, M. 2012. Character Education Consepts and Models. Bandung: PT Remaja Rosdakarya.

[13] Santrock, J. W. 2012. Educational Psychology. Jakarta: Salemba Humanika.

[14] Selfi, P. C., Muhardjito, \& Sutadji, E. 2016. Development of Authentic Assessment Instrument at Grade Four Elementary School in Malang. Proceedings of International Conference Proceeding on Educational Research and Evaluation (ICERE), Rectorate Hall and the Graduate School, Yogyakarta State University, Yogyakarta, May 29-31.

[15] Singh, S., Samad, A., \& Husen, H. 2015. English Language Teaching. Kanada: Canadian Center of Science and Education

[16] Suharnan. 2011. Creativity: Theory and Development. Surabaya: Laros.

[17] Sutadji, E., \& Wedi, A. 2015. Development of Vocational Education Evaluation Model-Based Curriculum 2013: Efforts Produce Students with Character and Creative Thinking to Achieve Vocational Competency. Research Report DPRM Year I. Malang: LP2M State University of Malang.

[18] Sutadji, E., \& Wedi, A. 2016. Development of Vocational Education Evaluation Model-Based Curriculum 2013: Efforts Produce Students with Character and Creative Thinking to Achieve 
Vocational Competency. Research Report DPRM Year II. Malang: LP2M State University of Malang.

[19] Uno, H. B. 2010. Education Profession: Problems, Solutions, and Education Reform in Indonesia. Jakarta: PT Bumi Aksara. 